


\section{HOGY VÉDEKEZZÜNK A SZELLEMI ALKOTÁSOK „KALÓZAI” ELLEN?}

\section{HOW TO DEFEND AGAINST THE "PIRATES" OF THE INTELLECTUAL PROPERTIES}

KERTÉSZ Gábor

Kulcsszavak: WIPO, szellemi tulajdon, szellemi tulajdon megsértése Keywords: WIPO, Intellectual property, Violate the intellectual property

JEL kód: K22, O34 


\section{ÖSSZEFOGLALÓ}

A szellemi tulajdon védelméröl szóló friss EU jelentés 121 milliárd euróra tesæi a „kalóztermékekkeel” okozott kárt. Arra keresem röviden a választ, hogyan lehetne hatékonyabb rendszert találni a jogtulajdonosok számára a „kalóz” termékek gazdaságilag káros hatásai ellen. A válasz̧boz történelmi, gazdasági és jogi példákat elemzęe, ami alapján

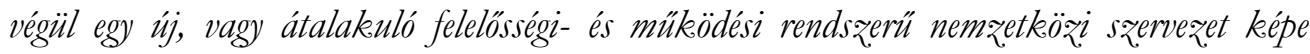
bontakozile ki, aminek müködése ü̃letileg tenné fölöslegessé, vagy veszteségessé a szellemi tulajdonjog megsértésének valamennyi eddig ismert gyakorlatát. A címbeli kérdés az elemzés

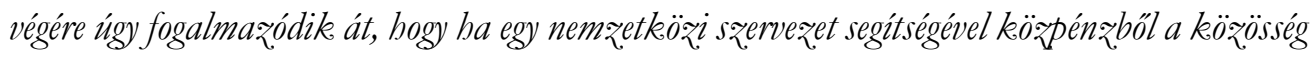
veszi meg a szellemi alkotásokat és ąt speciális adó fizetése ellenében engedi gyártani bárkinek, akekor üzletileg van-e értelme „kalózkodásra” és az ellene való védekezésre költeni.

\section{SUMMARY}

$A$ recent $E U$ report on the protection of intellectual property estimates in the damage caused by "pirated products" to $€ 121$ billion. I am looking for a brief answer how to find a more effective legal protection system for rightholders against the negative effects of the "pirated" products. To find an answer, I analyze historical, economic, and legal examples that ultimately give the impression of an international organization with a new or changing system of responsibilities and operations, the operation of which would make all known intellectual property right infringement practices commercially redundant or unprofitable. By the end of the analysis, the question arises as to whether, with the help of an international organization, the community buys intellectual property from public funds and allows it to be produced for a special tax, whether it makes commercial sense to spend on "piracy" and defense against it.

\section{BEVEZETÉS - A szellemi tulajdon megsértésének mértéke az EU-ban}

A Bizottság közzétette a szellemi tulajdon harmadik, EU-n kívüli országokban való védelmérôl szóló dokumentumát 2020. január 8-án SWD(2019)452 szám alatt.

A jelentés három csoportba sorolja a szellemi tulajdon sértéssel érintett államokat. A kereskedelempolitikáért felelős biztos, Phil Hogan szerint az EU teljes exportjának mintegy 82 százalékát a szellemi tulajdontól függő ágazatok adják. Mivel napjainkban nem csak az iparhoz, de a kereskedelemhez és a hétköznapi civil élethez is elengedhetetlenül hozzákapcsolódnak védett szellemi alkotások, hosszú távon elengedhetetlen egy olyan világszintű rendszer kialakítása és múködtetése, ami a jogtulajdonosok és a közösségek érdekeit egyaránt védi. Ilyen szempontból sajnálatos, hogy a jelenség csak az export és import „,kalóztermékek” értékét vizsgálja, az egységes belsô piacon belül forgó kalóztermékek értékét nem. 
A szellemi tulajdon megsértése - ezen belül a kikényszerített technológiatranszfer, a szellemi tulajdon „ellopása”, a hamisítás és a kalóztevékenység - évente több százezer munkahelyet fenyeget az EU-ban. A jelentés szerint éves szinten az EUba import révén bekerülő „kalóz” termékek 121.000.000.000 € értéket tettek ki. A világ többi részére került „kalóz” termékek értékére ez alapján lehet becsléseket tenni. Ugyancsak fontos rögzíteni, hogy ez a 121 milliárd $€$ nem kizárólag az EU rezidens jogtulajdonosok megkárosításával készült kalóz termékek értéke, hanem minden olyan kalóztermék összesített értéke, amely után a világon bárhol rezidens jogtulajdonos nem kapta meg az ôt megilletố jogdíjat.

Az alábbiakban „szellemi tulajdon védelme” alatt a szellemi alkotások jogának minden területén (pl. szerzői jog, szabadalmi jog, védjegyjog) az emberi alkotótevékenység révén létrehozott alkotások védelmét értem a szerzői mûvektől az ipari mintákon és a védjegyeken át az üzleti titokként a jog más területei által védett know-how formákig, kivéve az előadómúvészi tevékenységeket.

Első lépésként fontosnak tartom megnézni, hogy az itt közölt 121.000.000.000 € nemzetgazdasági szinten jelentős összeg-e?

A jogtulajdonos a szellemi alkotások zöménél nem egy tagállam, vagy az EU, hanem jellemzően profitorientált magánvállalkozás. Így a tagállam és az EU költségvetését nem a teljes jogdíj bevétel hiányával, hanem az ezen bevételekre vonatkozó adó meg nem fizetésében éri veszteség (vö. 2016/943\{L157/1\} 1. cikk). Mélyreható statisztikai és makrogazdasági elemzéseket mellőzve csak az EU 2019-es költségvetésében szereplő bevételi adatait vizsgálom, hiszen az „köztudomású tény”, hogy a költségvetési bevétel az adóalanyok befizetéseiből származik. Az EU 2019-es költségvetésének bevételi főösszege 144.680.980.690 $€(218 / 251\{\mathrm{~L} 57 / 1\})$.

A számok egyszerú összehasonlítása alapján is megállapítható, hogy a „kalóztermékek” összértéke nem sokkal mard el az EU éves költségvetési bevételének összegétől. Ebből viszont egyértelműen következik, hogy elengedhetetlen szükség van a szellemi tulajdon megsértésének hatékony megelőzésére.

\section{TÖRTÉNELMI PÉLDÁK}

Gazdasági joggal foglalkozó jogászként, akinek a jogtörténet is szakterülete, a jogtulajdonosok védelmét talán elsô ránézésre újszerủ, de alapjaiban 
hagyományos oldalról közelítem meg. Talán ma is érvényes a római mondás „historia est magistra vitae”, a „történelem az élet tanítómestere”. Egy másik régi római mondás szerint „Scientia potentia est”, „,a tudás hatalom”. A gazdaság oldaláról megközelítve a mondást úgy is fordíthatjuk, hogy „scientia est pecunia”, „a tudás pénzt ér”.

A történelemben gyakran találunk olyan eseteket, amikor egy közösség azáltal tudott gyorsan nagyot fejlődni, hogy valamilyen módon megszerezték egy másik, náluk technikailag fejlettebb közösség „high-tech”eszközének egy példányát, azt megvizsgálták és ez alapján saját gyártókapacitásuk hamarosan elő tudta azt állítani, így csökkentve saját közösségük technikai lemaradását. Erre a módszerre a történelem során a legkorábbi társadalmak óta a világ minden táján találunk gyakorlati példákat. Ezek a tevékenységek nagyon gyakran valamilyen harcérintkezéssel mentek végbe, ahol a technikailag fejletlenebb közösség harcban megszerzett (,zsákmányolt” vagy „ellopott”, a megnevezés egyéni ízléstől függ) egy fejlett technikájú eszközt, azt szakembereivel alkotóelemeire szedte, és megvizsgálta annak elkészítési lehetőségét. Mai fogalmaink szerint ez „függő szabadalom" használatáért való kényszerengedély kiadásaként (1995. évi XXXIII. törvény $114 /$ B. \) vagy valamely szellemi tulajdonjog elleni bűncselekményként (2012. évi C. törvény 384 - 388/B. \$) értelmezhető

A világtörténelemben erre számtalan példát találunk, itt most csak két történelmi példát említek a sok közül. Az egyik esetben azt tovább is fejlesztették, míg a másik esetben a változtatás nélküli sorozatgyártás valósították meg.

1. A köztársaság kori Róma nem rendelkezett tengeri haderővel, de kereskedelmi hajóval is alig, egészen az első pun háborúig (Kr.e. 264-241). A háború elején a tengeri hatalom Karthágó egyértelmúen uralta a vizeket. A legenda szerint egy partra sodródott karthágói hajó alapján kezdték felépíteni a római flottát (Polybios, 2002). Ezt a karthágói hajótípust a rómaiak továbbfejlesztették a corvus (csapóhíd) felszerelésével, ami mai fogalmaink szerint függő szabadalom volt, de ez tette lehetôvé, hogy a rómaiak a tengeri ütközetekben is alkalmazni tudják szárazföldi taktikájukat úgy, hogy az ellenséges hajón kézitusát vívtak az ellenséggel. Az „ellopott” szabadalom és az ennek révén fejlesztett függő szabadalom már a Kr.e. 260 Mylae-i ütközetben győzelmet hozott Rómának. A római flotta gályái a következő évszázadokban is hasonlóan néztek ki és az itt tanult taktikát alkalmazták. Ebben a példában azt láttuk, hogy Róma maximálisan kihasználta az „ellopott” technikában rejlő lehetőségeket és azt tovább is fejlesztette saját technológiai szükségletei szerint. 
2. A másik példa sok száz évvel későbbi, és a Föld átellenes pontjáról való. Japán a tűzfegyverekkel akkor ismerkedett meg, amikor 1543-ban egy portugál hajó az egyik Japán sziget partjainál szenvedett hajótörést. A tűzfegyvereket a japán hadurak gyorsan megismerték és hamar felállították saját fegyvergyártó iparukat és muskétás egységeiket. Viszont mivel a tűzfegyver használatát erkölcsi rendjükben nem tartották magas szintűnek, a technikát csak használták, nem fejlesztették. Így amikor 1853-ban több évszázados elzárkózás után Japán újra kapcsolatba került a világ többi részével, az amerikaiak a japán hadsereg fegyverzetében olyan tűzfegyvereket találtak, amiket Európában a 16. században használtak.

A fenti két példa is azt mutatja, hogy az emberek a legrégebbi korok óta próbálják kifürkészni mások felfedezéseit (felfedezés alatt értve az emberi tevékenység alapján alkotott új eredményeket, függetlenül attól, hogy azok a tudomány és a szellemi alkotások jogának mely területére vonatkoznak), találmányait, amit aztán vagy változtatás nélkül, vagy továbbfejlesztve fel is használnak. Ez a - talán mondhatjuk alapvető emberi - kíváncsiságot kielégítő igény napjainkban is jelen van, és sok helyen egy másik alapvetô igénnyel, a titokvédelemmel kerül szembe. A két ellentétes igény kielégítésére egész iparágak épültek ki, amit ipari kémkedésnek és adatvédelemnek nevezünk. Az ipari kémkedést mai fogalmaink és kultúránk szerint alapvetően jogellenesnek tartjuk, függetlenül attól, hogy a legtöbb állam és több vállalat is végez ilyen titkos, „fürkésző” tevékenységet, miközben fejleszti adatvédelmi képességeit, hogy az ő titkait más ne szerezhesse meg. A kérdést napjainkban még az is bonyolítja, hogy az új felfedezéseket a felfedezôk/kutatók sok esetben a jogvédelem biztosítása és az ipari alkalmazás előtt tudományos szimpóziumokon ismertetik, publikálják. Ez pedig jelentősen megkönnyíti az új „felfedezés” jogdífizetés nélküli felhasználásának a veszélyét nem csak azért, mert a „felfedezés” önmagában jogilag nem oltalomképes, hanem mert a „megrendelő” szakemberei át tudják alakítani a megismert „felfedezést”, hogy a köztük lévő kapcsolatot elfedjék. A szabadalmi jog világszerte megköveteli, hogy a feltaláló a szabadalmi újdonságot a szakemberek számára érthetően „feltárja” a szabadalmi hatóság előtt, amely a védelem megadásával egyidejúleg hivatalos lapjában közzéteszi a szabadalmat, szakértő számára érthető és megvalósítható módon (ld.: 1995. évi XXXIII. tv. 60.\$ (2) bek.). 


\section{A TUDÁSÁTVÉTEL JOGSZERÜTLEN FORMÁI}

A határvonal a tudományos kutatás és az ipari kémkedés között időnként elmosódik, mivel az ipari kémkedéssel foglalkozó szervezetek saját változatos titkos tevékenységük mellett jellemzően használják a nyilvánosan publikált tudományos közlemények elemzését is. Így az ilyen ügyeket vizsgáló ritka eljárásokban szakmai - és nem politikai vagy üzleti - oldalról az a legfontosabb kérdés, hogy el lehessen határolni egymástól a (legtöbb ország jogában bűncselekménynek számító) ,adatlopást”, a tudományban elítélt plagizálást és a szabályos forrásmegjelölést. Tankönyvszerūen ezeket könnyen el lehet különíteni az egyes definíciókkal, a gyakorlati esetekben viszont jellemzően sokkal összetettebb példákkal találkozunk, amik akár mindhárom forma egyes jegyeit is magukon viselik (Erdősi, 2005).

Még ha az ipari kémkedést, szellemi tulajdon „lopást” a bíróság ítéletével meg is állapítja, és meghozza a törvényes ítéletet, találkozunk egy újabb problémával. A kémkedő utóbb a terméket saját tulajdonú berendezéssel, saját alapanyagból készíti el, megsértve a jogtulajdonos jogát. Egy analógia a büntetőjog területéről a jogsértés és az itélet kapcsolatára: Alapvető alkotmányos szabály a büntető eljárásban, hogy a törvényellenesen beszerzett bizonyítékot a bíróság nem használhatja fel. Viszont, ha a nyomozó bár törvényellenesen - így a bírósági eljárásban felhasználhatatlanul - megszerzi a bizonyítékot, abból az ismert adatból már könnyebb - most már törvényes módon - ugyanezt az adatot megszerezni, hiszen pontosan tudja, mit keres. Vagyis ha az „adatlopással” megszerezte a szükséges információt, abból saját szaktudásával már könnyebben tud új eljárást megalkotni azonos eredmény megszerzésére. Ilyen esetben viszont a bíróság nem tud jogsértést megállapítani, hiszen az új termék az azonos vagy hasonló eredményt teljesen más úton éri el, mint a jogvédett korábbi szabadalom.

Az ember a hasznos, eredményes megoldásokat általában nem szokta elhagyni, amíg nem talál egy másik, lényegesen jobb megoldást. Napjainkban mind az állami, mind a magán titkosszolgálatok jelentős erőket mozgósítanak az ,ipari kémkedésre" és más államok, illetve ma már egyes esetekben magáncégek ellenük kifejtett ipari kémtevékenysége elleni védekezésre. Az új technikát átvevő közösség pedig a legritkább esetben - mai fogalmaink szerint - fizetett jogdijat az átvett technika gyártásáért, használatáért. Valójában ez a jogsértő tevékenység segítette az egész emberiség technikai fejlődését. A szellemi alkotások joga, ami védi a jogtulajdonos anyagi érdekeit, csak a XIX. század második felében kezdett kialakulni, addig csak a (mai fogalmaink szerinti) know-how titkossága adott 
védelmet, de az ellen semmi nem védett, ha egy másik személy a termék példányának vizsgálatával megfejtette a titkot. Amíg a gyártókapacitások korlátozottak és a gyártósorok lassúak voltak, a tudomány-technika aktuális állapota biztosított tényleges védelmet a jogtulajdonosnak, hiszen egy „kalóztermék” elóállításához gyártókapacitást kellett volna készíteni, ami mindenképpen jelentôs kiadást igényelt, így azt gazdaságilag csak ipari méretben érte meg végezni. Ez vezetett ahhoz a jelenlegi helyzethez, hogy az előadóművészeti alkotások kivételével a jogsértést jellemzően nem magánszemélyek követik el, akik a büntetôjog hagyományos alanyai, hanem különféle vállalkozások, akik transznacionális vállalatcsoporti szervezeti hálójuk, esetleg valamely állam jogalkotásának és jogalkalmazásának „félrenézése” révén még hosszú, alaposan bizonyítékokkal alátámasztott perek után sem kötelezhetók a jogdíj megfizetésére a jogtulajdonos felé.

Az elemzés szerint az okozott kár zöme a design és a védjegy sértésekből kerül ki, hiszen itt a termék elkészítése általában a jogvédelemmel érintett tartalom mellett az alapanyag költség elenyésző. Ezek jellegüknél fogva a szellemi tulajdon azon területei, ahol a „kalóz” termékek könnyen elóállíthatóak az eredteti/jogtiszta terméket elóállítónál jóval olcsóbb bekerülési és múködési költségű gyártósorokon is. A károk iparterület szerinti bontása pedig azt mutatja, hogy a legtöbb kár a kozmetikumok, a rovarirtók és mútrágyák körében, valamint a ruhaiparban keletkezik.

Üzleti és takarékossági oldalról közelítve a helyzethez, talán érdemes elgondolkodni egy olyan megoldáson, hogy a jogsértő termékből befolyt bevételt egy nemzetközi egyezményben meghatározott arányban osztják meg a jogtulajdonos és a (jogsértő) terméket előallító között, hiszen a jogsértő előállítás során szükségszerűen felmerül anyagköltség és előállitási költség a jogvédelem alá eső termék létrehozása során. Amennyiben az így készült termék a minőségellenőrzés szerint nem éri el a „lemásolt” eredeti termék minőségét, az ugyancsak itt rögzíthetô, hogy az elóállító tartozik a vevő felé kártérítéssel (vö. termékfelelősség Ptk. LXXII. fejezet), vagy az eredeti és a hamisított termék árkülönbözete betudható kártérítésnek.

\section{TEORETIKUS ÉS GYAKORLATI PROBLÉMÁK A JELENLEGI RENDSZERREL}

A jogrendszer a szellemi alkotások jogának kialakulása óta a jogvédelmet ex post alapokra helyezi, ami a jogosult aktív közremúködését követeli meg. A szellemi 
alkotások jogvédelme a XIX. században jelent meg és vált a XX. század első felére önálló jogterületté. Napjainkban az ilyen tárgyú nemzetközi egyezmények mellett az egyes országok nemzeti jogalkotásai jellemzően az üzleti titok védelme felől közelítik meg a kérdést, amely tárgykörben hazánk is folyamatosan veszi át és fejleszti a külföldi megoldásokat (2018. évi LIV. tv. az üzleti titok védelméről).

Abban a Föld összes jogrendszere egyetért, hogy a szellemi tulajdonjog megsértésével kapcsolatos jogviták a magánjog területére tartoznak, bár a büntetójog is szankcionálja ezeket a cselekményeket (Btk. XXXVII. fejezet). Abban ugyancsak teljes az egyetértés, hogy magánjogi jogvitában a bíróság csak a jogosult keresetére indít eljárást, amely során nincs officialitás, a bíróság csak az elé terjesztett bizonyítékok alapján hoz döntést és a kereseti kérelmen nem terjeszkedik túl. Az eljárás megindítása, az országonként eltérő, jellemzően szociálpolitikai indokból lehetôvé tett illetékmentességi formákat nem tekintve, az eljárás kezdeményezőjének a költsége, valamint az ügyvédi munkadíjat is az utófinanszírozás esetét kivéve neki kell fizetnie. Ez független attól, hogy a legtöbb állam jogrendszere szerint a bíróság a pervesztest kötelezi a fơkövetelés mellett az eljárási illeték és a pernyertes ügyvédi költségeinek megfizetésére is. A legtöbb állam jogrendszere, ha a pervesztes fél határidőig nem fizeti meg a megítélt összeget, valamilyen állami közremúködéssel segít ennek behajtásában, jellemzően újabb külön kérés és díj ellenében. Vagyis a bírósági jogérvényesítés során a sérelmet szenvedett jogtulajdonosnak a jogsértés miatti sérelmén túl, annak országonként eltérő százalékát kitevő további költségei merülnek fel a jogérvényesítés érdekében, amit csak az eljárás végén kap meg.

A jelenlegi jogi szabályozási rendszer az imént vázolt eljárási folyamatok mellett kvázi szükségszerúen eredményezte azt a helyzetet, hogy a szellemi tulajdonjogot érvényesíteni tudó jogtulajdonosok döntő többsége tőkeerős vállalkozás, akik likviditási problémák nélkül tudják végigvinni ezeket a jogi eljárásokat, amik országonként eltérő, de jellemzően több év hosszúak, mire a jogtulajdonos „pénzéhez jut”.

Tudjuk, hogy a tudomány-technika mai fejlettsége mellett a technikai újdonságok, vagyis a szellemi tulajdonjog tárgyai kevés kivételtől eltekintve, ha kezünkben van az adott technikát jogtisztán használó és általunk jogtisztán megszerzett eszköz, elóttünk is feltárhatóvá válnak, mindehhez különböző vizsgálati technikák szükségesek, melyek közül jó néhányat az egyetemek BA tananyagban (nem a jogsértést könnyítendô) oktatnak. Nem kell a szabadalmi jog által előírt kötelező 
feltárást lapozgatnunk a (talán ma már nem is olyan) régi hivatalos lapokban, de a hivatalosan fel nem tárt technikákat (ld. know how) is meg tudjuk ismerni/fejteni. Azt a hosszú idô óta ismert gyakorlatot az EU jelentése is tényként állapítja meg, hogy több országban kvázi „nagyüzemi” méretekben folyik a szellemi tulajdonjogok megsértése.

A büntetőjogászok már az előzô századfordulón azt mondták, hogy tökéletes jogkövetés illetve minden jogsértés szankcionálása kizárólag a Pokolban van, de oda senki nem akar kerülni. Vagyis írhatunk bármilyen jogilag tökéletes törvényt vagy szerződést, teljesen biztosak lehetünk benne, hogy ennek ellenére is lesznek a piacon jogsértő tartalmak, amik után nem kapja meg a jogosult a jogdíat. Ez a filozofikus mondat, aminek igazságtartalmát mind a joggyakorlatban, mind a törvényhozási gyakorlatban gyakran látjuk bizonyítva, felveti az ötletet, hogy más oldalról keressünk hatékonyabb védelmet a jogtulajdonosok jogdíjbevételeinek biztosítására.

A szerzői jogok közül a gyakorlatot - és a jogosultakat - leginkább a vagyoni jogok érdeklik (kap-e jogdíjat). A szerző személyhez fűződő joga, a névjog leginkább a tudományban bír relevanciával, ott pedig jellemzően az első adott tárgyú eszközre hivatkoznak, ami ezek a tudományos anyagok szinte kivétel nélkül feltüntetnek. A gyakorlat az első szerzői jogi egyezmények óta ismeri és a szellemi alkotások joga egyre növekvő arányban alkalmazza azt a gyakorlatot, hogy a szerző értékesítheti a szellemi alkotáshoz fűződő vagyoni jogait. A vagyoni jogok értékesítését részleges és teljes formában is ismeri a gyakorlat. Így a vagyoni jogokat el lehet adni időbeni hatállyal véglegesen, vagy határozott időre (tulajdonképpen bérbe adva a szellemi alkotás felhasználását meghatározott időre) illetőleg területi hatállyal világszerte, vagy meghatározott földrajzi területen való felhasználásra. Fontos megállapítani azt a tényt is, hogy a római-germán és az angolszász jogi kultúrában a rómaiak óta ismert „nemo plus iuris ad alium transfere potest quam ipse habet" (senki sem ruházhat át több jogot, mint amivel o maga rendelkezik) szabály a világ többi jogi kultúrájában is ugyanilyen tartalommal létezik. Ha a szellemi alkotás korlátozás nélküli, teljes tulajdonjoga egy tőkeerős szervezethez kerül, az nagyobb hatékonysággal tudja érvényesíteni érdekeit a jellemzően hosszú és drága bírósági és végrehajtási eljárás során, mint egy magánszemély, vagy nem tőkeerős szervezet. A legtöbb országban vannak a magyar terminológia szerint ún. „közös jogkezelő” szervezetek, amelyek a szerzők és előadóművészek vagyoni jogait védik, hiszen a tudomány, technika mai szintjén 
egy alkotás számtalanszor lejátszható nem privát használat keretében. Ezek az országos szervezetek egymással nemzetközi kapcsolatban vannak, ennek révén fel tudnak lépni saját országukban egy másik országból való szerző vagy előadó jogdija érdekében. Sok országban a jogalkotó és az állami szervek sajátos megoldásokkal támogatják a szerzôket a közös jogkezelő szervezeteken keresztül. A legtöbb ország jogrendszere ismeri az „üres kazetta dij” intézményét, ahol az üres adathordozó eszköz értékesítése után szabott díjat kell fizetni a közös jogkezelőnek, hiszen a vevő arra bármilyen jogdíjköteles alkotást felmásolhat, a díjat pedig a jogkezelő osztja szét a nála regisztrált valamennyi szerző között az általa meghatározott módon.

Létezik a szellemi tulajdonnak nemzetközi egyezménye és világszervezete (World Intellectual Property Organization, WIPO). Jelenleg a WIPO 193 tagállammal rendelkezik. A WIPO tagállamaiban múködő közös jogkezelő szervezetek főleg az előadó-múvészetben használható alkotások, és az ezek előadását jelentő előadóművészi teljesítmények vagyoni jogainak védelmével foglalkoznak. Napjainkban ezek általában jó és növekvő hatásfokkal tevékenykednek a jogosultak jogvédelme, jogérvényesítése területén (WIPO, 2019). A ma világszerte használt internet-alapú fogyasztói kultúrában a jogkezelő szervek mérni tudják, hogy az egyes jogvédett alkotásokat hol és hány alkalommal játszották le, így fel tudnak lépni a konkrét fogyasztókkal szemben. Ugyanezen adatokból az „üres kazetta dîj” elosztását is reálisabbá tudják tenni.

Egy nemzetközi jogalanyisággal rendelkező szervezet jogilag szerzőképes, meg tudja szerezni a szellemi alkotáshoz fűződő vagyoni jogokat. Ha ennek az új, vagy új jogokkal felruházott, de már jelenleg is létező nemzetközi szervezetnek kellő forrást biztosítunk tagállami tagdíjbefizetés révén, ez a szervezet (akár előre, akár utólagos fizetési vagy a tényleges felhasználási gyakorisághoz kötött konstrukcióval) meg tudja venni a szerzőktől a vagyoni jogokat. Ezáltal az adott tagállam belső jogilag válik érdekeltté a „kalóz” termékek gyártóitól valamilyen jogcímen (pl. spec. adónem) beszedni a jogalanyaik által végzett „kalóz” tevékenységre tekintettel fizetendő nagyobb összegú tagdíjat, hiszen a szerzők a szervezetnek adták el a vagyoni jogokat, aminek ő (az állam) is tagja, és a fizetendő tagdíj kiszámítása függ az adott államban korábban elkövetett szellemi jogsértéssel okozott kár összegétől. A tagdíj számítási képletben figyelemmel kell lenni az érintett állam jogalanyai által előző évi jogsértő tevékenységekkel okozott kár összegére, amit az ország ipara által a jogvédett termékek felhasználásával 
(elsődlegesen gyártásával) elért. Az egyes államok statisztikai hivatalai gyűjtik az adatokat a náluk gyártott jogvédett termékekről és közvetett számítással kalkulálják a szellemi tulajdon sértéssel okozott kár mértékét is.

A szellemi tulajdon megsértésében érintett országoknak egyes hírek szerint az EU országaiban ismerteknél hatékonyabb módszereik vannak az adók beszedésére. De talán az is az érintett vállalatok önkéntes adófizetési hajlandóságát növelheti, hogy egy ilyen rendszer révén a vásárló biztos lehet abban, hogy „jogtiszta” szellemi alkotást vett. Az pedig az államok saját döntése, hogy bevezetnek-e olyan árujelzőt, aminek használata igazolja, hogy az adott vállalkozás befizette a termelés szerinti államban a szellemi alkotások ,jogtisztaságát”, vagyis az illetékes nemzetközi szervezeti tagdíja érdekében megállapított díjat, ami talán növeli a terméknek marketing értékét is.

\section{KONKLÚZIÓ}

A fentiek alapján két dolog teljes bizonyossággal kimondható: (1) a szellemi alkotások jogdífizetés nélküli használata, valamint továbbfejlesztése talán az emberiséggel egyidôs, történelmi példákat az ókor óta ismerünk; és (2) ez a jogsértés napjainkban hatalmas összegeket tesz ki egyrészt a jogtulajdonosoknál, másrészt az így kieső adóbevételek révén az államok költségvetésében több százalékos lukat üt.

Az eddigi tapasztalatokat végignézve egy olyan, az ENSZ keretein belül múködô szervezet felállítása túnik praktikus megoldásnak, amely minden típusú szellemi alkotások jogait felvásárolja és biztosítja a „jogtiszta” felhasználást a tagállamok jogalanyainak. A szervezet múködését a tagállamok által fizetendő tagdíjból lehetne fedezni, amelynek tagállamonkénti megállapításában az adott államban előző évben megvalósuló jogsértő tevékenységek, és az itt ilyen módon elkészülő szellemi alkotások értéke alapján elfogadott képlet szerint lehetne meghatározni. Egy ilyen rendszer megfelelő kalibrálás mellett üzletileg feleslegessé teheti a szellemi tulajdonsértések jelenlegi gyakorlatát, ami a jogvédelmi rendszer fenntartását is okafogyottá teheti. Mindez két oldalról hatalmas forrásokat nyitna meg a gazdaság előtt és segítené a tudományos, technológiai innováció sebességének fokozását is a felszabaduló források ide csatornázásával. 


\section{FELHASZNÁLT IRODALOM}

1. European Commission: SWD (2019)452

2. European Parliament: 2018/251 (28/02/2018) L57/51

3. European Parliament and the Council 2016/943 (L157/1)

4. Erdősi, Csaba (szerk.): Az ipari kémkedés és az üzleti hírszerzés. BMGE, Budapest, 2005.

5. Polybios: Historiae. fordította: Muraközy György, Attraktor, Gödöllő, 2002.

6. WIPO: World Intellectual Property Report, 2019. WIOP, Geneva, 2019.

7. 2018. évi LIV. törvény. az üzleti titok védelméről

8. 2012. évi C. törvény a büntető törvénykönyvről

9. 1995. évi XXXIII. törvény a találmányok szabadalmi oltalmáról 
ISSN 2630-886X

18 国 57
BGE 